\title{
ХРОНІЧНА СЕРЦЕВА НЕДОСТАТНІСТЬ У ХВОРИХ ПОХИЛОГО ВІКУ З ІЗОЛЬОВАНОЮ СИСТОЛІЧНОЮ АРТЕРІАЛЬНОЮ ГІПЕРТЕНЗІЄЮ
}

\author{
๑С. О. Шейко, Н. О. Кол6 \\ ДЗ «Дніпропетровська медична академія МОЗ України»
}

PЕзЮМЕ. У пацієнтів з ізольованою систолічною артеріальною гіпертензією (ІСАГ) до розвитку хронічної серцевої недостатності (ХCH) призводять тривалий перебіг хвороби, структурно-функціональна перебудова та порушення геометричної моделі серця. Певний внесок у формування ХCH зі збереженою фракцією викиду (ХСНзбФВ) лівого шлуночка (ЛШ) у хворих похилого віку мають вікові зміни серця. Незважаючи на значні успіхи в діагностиці і лікуванні хворих похилого віку з ІСАГ, особливості розвитку та критерії діагностики ХСН у даної категорії пацієнтів на даний час залишаються недостатньо вивченими.

Мета - вивчити особливості розвитку та розробити критерії діагностики ХСН у хворих похилого віку з ІСАГ.

Матеріал і методи. Обстежили 134 хворих похилого віку з ІСАГ. До основної групи увійшов 91 пацієнт віком $(71,1 \pm 3,5)$ років з ІСАГ, з ФВ ЛШ >50 \% та рівнем NT-рго BNP>125 пг/мл, в тому числі 61 жінка (67 \%) і 30 (33 \%) чоловіків. Групу порівняння склали 43 пацієнти $(27$ жінок і 16 чоловіків віком $(70,4 \pm 3,7)$ років) з ІСАГ, ФВ ЛШ>50\% та NT-рго BNP <125 пг/мл. Структурно-функціональний стан серця вивчали за допомогою одно-і двовимірної ехокардіографії. Об'ємні показники ЛШ та лівого передсердя (ЛП) розраховували за методом Simpson. Трансмітральний кровотік оцінювали за рекомендаціями Європейської асоціації кардіоваскулярної візуалізації та Американської асоціації ехокардіографії. NT-рго BNP у плазмі крові визначали за допомогою хемілюмінесцентного імуноферментного аналізу.

Результати. У 66 (72,5 \%) хворих основної групи діагностовано діастолічну дисфункцію (ДД) за типом порушення релаксації (ПР) ЛШ. У 25 (27,5 \%) пацієнтів з ІСАГ і ХСНзбФВ діагностували порушення діастолічної функції (ДФ) за типом псевдонормалізації (ПН). В усіх випадках мала місце концентрична ГлШ. Незалежно від статі рівень індексу максимального об'єму ЛП (ІОЛПмакс.) перевищував 34 мл/м². Розроблено критерії діагностики ХСНзбФВ ЛШ у хворих з ІСАГ: наявність клінічних симптомів СН при значеннях ФВ ЛШ >50 \%, рівня Nt-pго BNP>125 пг/мл, концентричного варіанта ремоделювання ЛШ, переважно концентричної ГлШ, ДД ЛШ за типом ПР (E/A<0,8) або ПН (E/A>0,8<2,0) та ІОЛПмакс. $>34$ мл/м².

Висновки. Провідним патогенетичним чинником виникнення ХСНзбФВ є ДД лш. Спектр порушень ДФ Лш залежить від профілю його ремоделювання. У 66 (73 \%) хворих з ІСАГ і ХСНзбФВ діагностовано ДД за типом ПР ЛШ. У 25 (27 \%) хворих спостерігали порушення діастолічного наповнення за типом ПН. Визначення профілю порушень ДФ ЛШ у хворих з ІСАГ і ХСНзбФВ необхідне для подальшого проведення диференційованої медикаментозної корекції його ДД.

КЛючОВІ СлОВА: ізольована систолічна артеріальна гіпертензія; хронічна серцева недостатність; збережена фракція викиду; діастолічна дисфункція; похилий вік.

Вступ. Незважаючи на значний прогрес у профілактиці й лікуванні серцево-судинних захворювань протягом останніх десятиліть, хронічна серцева недостатність $(\mathrm{XCH})$ залишається найпоширенішим ускладненням уражень міокарда різної етіології, яке характеризується тяжкістю клінічних проявів та незадовільним прогнозом виживання [1-4]. Традиційно ХCH пов'язують із порушеннями скорочувальної функції лівого шлуночка (ЛШ). Однак, згідно з сучасними уявленнями, систолічна дисфункція розглядається лише як один із факторів розвитку $\mathrm{XCH}$, поряд зі змінами напруження стінок і структури діастолічного наповнення.

За даними національних реєстрів європейських країн, близько 50 \% хворих із клінічними симптомами ХСН мають збережену фракцію викиду (ФВ) ЛШ [5-8]. Проте смертність хворих із ХСН зі збереженою ФВ ЛШ (ХСНзФВ) ЛШ $\epsilon$ високою [5]. В останні роки в контексті розвитку ХCH особливу увагу науковців привертає діастолічна дисфункція (ДД) ЛШ. Доведено, що порушення розслаблення і наповнення шлуночків серця в діастолу $\epsilon$ найпершими ознаками практично всіх органічних захворювань серця і реєструються задовго до розвитку порушення систолічної скоротливої активності міокарда і клінічної симптоматики серцевої недостатності (CH) [9]. Водночас ДД характеризується складністю ранньої діагностики, безсимптомним їі перебігом та пізнім звертанням пацієнтів до лікаря.

Сучасні клінічні рекомендації різних медичних асоціацій високого рівня репутації надають великого значення вдосконаленню методів ранньої діагностики, профілактики та індивідуалізованого лікування ХCH.

Артеріальна гіпертензія (АГ) залишається одним із найпоширеніших захворювань серцево-судинної системи в Україні, яке значно погіршує 
Огляди літератури, оригінальні дослідження, погляд на проблему, випадок з практики, короткі повідомлення прогноз виживання таких хворих, супроводжується збільшенням витрат на лікування та частоти госпіталізацій $[7,10,11]$. У пацієнтів з ізольованою систолічною артеріальною гіпертензією (ICAГ) до розвитку ХСН призводять тривалий перебіг хвороби, структурно-функціональна перебудова та порушення геометричної моделі серця. Певний внесок у формування ХСН мають вікові зміни серця. 3 віком відбувається зменшення еластичності серця і магістральних судин. Це призводить до підвищення систолічного артеріального тиску і жорсткості міокарда. Жорсткість артерій - це незалежний предиктор ДД ЛШ і зменшення резерву коронарного кровотоку.

Незважаючи на значні успіхи в діагностиці і лікуванні хворих похилого віку з ІСАГ, особливості розвитку та критерії діагностики ХCH у пацієнтів похилого віку на сьогодні залишаються недостатньо вивченими.

Мета - вивчити особливості розвитку та розробити критерії діагностики хронічної серцевої недостатності у хворих похилого віку з ізольованою систолічною артеріальною гіпертензією.

Дослідження є фрагментом науково-дослідної роботи кафедри педіатрії, сімейної медицини та клінічної лабораторної діагностики Дніпропетровської медичної академії «Обґрунтування комплексних підходів до клініко-лабораторної діагностики, профілактики і лікування захворювань кардіореспіраторної системи та коморбідних станів у віковому аспекті» (державний реєстраційний № 0117 U 004728).

Матеріал і методи дослідження. Дослідження здійснено відповідно до стандартів належної клінічної практики та принципів Гельсінської декларації на клінічній базі кафедри педіатрії, сімейної медицини та клінічної лабораторної діагностики ДЗ «Дніпропетровська медична академія МОЗ України КНП «Центру первинної медико-санітарної допомоги № 2 Криворізької міської ради». Після отримання інформованої згоди було проведено обстеження 134 хворих похилого віку з ІСАГ. За результатами обстеження пацієнтів поділили на клінічні групи. До основної групи включили 91 пацієнта віком $(71,1 \pm 3,5)$ років з ІСАГ, з ФВ лШ $>50 \%$ та рівнем натрійуретичного пептиду (NT-рго BNP) >125 пг/мл, в тому числі 61 жінку (67 \%) і 30 (33 \%) чоловіків. Групу порівняння склали 43 пацієнти (27 жінок і 16 чоловіків віком $(70,4 \pm 3,7)$ роки) з ІСАГ, ФВ ЛШ >50 \% та NT-рго BNP <125 пг/мл. Середня тривалість захворювання у пацієнтів основної групи була $(7,5 \pm 1,0)$ років, у пацієнтів в групі порівняння - $(7,1 \pm 0,8)$ років. Обидві клінічні групи були статистично зіставними за віком ( $p=0,902$ за t-критерієм), статтю ( ICAГ ( $p=0,796$ за t-критерієм).

Діагностику ХСНз6ФВ здійснювали згідно з рекомендаціями Української асоціації кардіологів (2017) та рекомендаціями Європейського товариства кардіологів 2016 року при наявності симптомів і ознак СН, ФВ ЛШ >50 \% і рівня натрійуретичного пептиду (NT-рго BNP) >125 пг/мл $[6,12]$.

Критеріями включення була наявність клінічних симптомів і ознак СН, ФВ ЛШ >50\%, рівень NT-pго BNP >125 пг/мл та похилий вік пацієнтів.

Критеріями не включення у дослідження були ожиріння, захворювання легень, цукровий діабет, гострий коронарний синдром, фібриляція та тріпотіння передсердь, тяжкі порушення провідності, вади серця, кардіоміопатія, системні захворювання сполучної тканини, захворювання щитоподібної залози, тяжка печінкова та ниркова недостатність, онкологічні захворювання та зловживання алкоголем.

NT-рго BNP у плазмі крові визначали за допомогою хемілюмінесцентного імуноферментного аналізу на аналізаторі Immulite 1000 (США).

Структурно-функціональний стан серця вивчали за допомогою одно- і двомірної ехокардіографії на апараті «Esaote.my lab class C» за стандартною методикою згідно з рекомендаціями Американського товариства з ехокардіографії та Європейської асоціації з ехокардіографії [13]. Об'ємні показники лШ та лівого передсердя (лП) розраховували за методом дисків (Simpson) та індексували за площею поверхні тіла.

Індекс жорсткості аорти (ІЖА) обчислювали як відношення між ПАТ та ударним об'ємом.

Трансмітральний кровотік оцінювали за рекомендаціями Європейської асоціації кардіоваскулярної візуалізації та Американської асоціації ехокардіографії [13]. Для оцінки діастолічної функції ЛШ визначали E/A - відношення максимальної швидкості раннього діастолічного наповнення (Е) до швидкості потоку під час систоли передсердь (А). Разом із показником Е це співвідношення дозволяє провести градацію діастолічної дисфункції на три типи: порушення релаксації, псевдонормальний і рестриктивний тип.

Статистичну обробку даних дослідження проводили з використанням методів параметричного і непараметричного аналізу за допомогою пакета програм Statistica v. 6.1 (серійний № AGAR909E415822FA). Гіпотезу про нормальність розподілу кількісних даних перевіряли за критерієм Шапіро - Уїлка при р<0,01. Середні дані представлені у вигляді середнього арифметичного (M) зі стандартною похибкою (m), відносні - як абсолютне значення і відсотки. Оцінку статистичної значущості відмінностей середніх величин проводили за t-критерієм Стьюдента для незалежних вибірок з урахуванням однорідності дис- 
Огляди літератури, оригінальні дослідження, погляд на проблему, випадок з практики, короткі повідомлення персій (критерій Фішера), відносних величин - за критерієм відповідності $\chi^{2}$ Пірсона, в тому числі з поправкою Йетса при малих значеннях. Для аналізу кореляційного зв'язку між різними факторами застосовували метод парної кореляції Пірсона (г). Значимими вважали відмінності при р<0,05.

Результати й обговорення. Основними клінічними проявами досліджуваних хворих основної групи були задишка, відчуття порушення ритму серця, загальна слабкість та підвищена втомлюваність при фізичних навантаженнях, наявність набряків нижніх кінцівок (табл. 1).

Таблиця 1. Частота виявлення основних суб'єктивних клінічних симптомів у хворих з ІСАГ (абс., \%)

\begin{tabular}{|l|c|c|}
\hline \multicolumn{1}{|c|}{ Симптоми } & $\begin{array}{c}\text { Основна група } \\
(\mathrm{n=91)}\end{array}$ & $\begin{array}{c}\text { Група порівняння } \\
(\mathrm{n}=43)\end{array}$ \\
\hline Задишка при фізичному навантаженні & $76(83,5 \%) * * *$ & $3(7,0 \%)$ \\
\hline $\begin{array}{l}\text { Загальна слабкість, швидка втомлюваність при } \\
\text { фізичному навантаженні }\end{array}$ & $80(87,9 \%)$ ** & $29(67,4 \%)$ \\
\hline Відчуття порушеного ритму серця & $50(54,9 \%) *$ & $15(34,9 \%)$ \\
\hline Наявність набряків нижніх кінцівок & $16(17,6 \%) *$ & $2(4,7 \%)$ \\
\hline Сонливість, збудження & $23(25,3 \%)$ & $15(34,9 \%)$ \\
\hline
\end{tabular}

Примітка. *- $p<0,05 ;$ **- $p<0,01 ; * * *-p<0,001$ відносно групи порівняння.

Структурно-функціональний стан серця у хворих похилого віку з ІСАГ і ХСН зі збереженою ФВ представлений різними варіантами ремоделювання ЛШ. У хворих основної групи переважала концентрична ГЛШ - у 73 (80,2 \%) пацієнтів, а в групі порівняння концентричне ремоделювання - у $25(58,1 \%)$ хворих ( $<0,01$ за критерієм $\left.\chi^{2}\right)$. Концентричне ремоделювання у пацієнтів з ІСАГ і ХСНзбФВ діагностували у 18 (19,8 \%) хворих. Концентричну ГлШ верифікували у 18 (41,9%) пацієнтів групи порівняння $(p<0,01)$.

Значення ОЛПмакс., незалежно від статі, перевищувало 58 мл, а рівень ІОЛПмакс. переви- щував 34 мл/м². У пацієнтів групи порівняння ІОЛПмакс. був у межах 27-32 мл/м², і в усіх випадках був <34 мл/м². Достовірне збільшення ОЛПмакс. та ІОЛПмакс. у хворих основної групи, порівняно з даним показником у пацієнтів з ІСАГ без XCH, загалом свідчить про значне збільшення об'єму ЛП, а значить і про збільшення його внеску в наповнення ЛШ при ІСАГ з ХСНзбФВ. Максимальний об'єм ЛП, віднесений до площі поверхні тіла, $є$ непрямим показником тиску наповнення лш.

Показники діастолічної функції лШ у хворих 3 ІСАГ із ХСН зі збереженою ФВ представлені в таблиці 2.

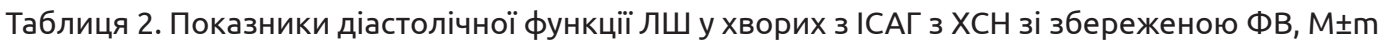

\begin{tabular}{|l|c|c|c|}
\hline \multirow{2}{*}{ Показники } & \multicolumn{3}{|c|}{ Типи діастолічної дисфункції } \\
\cline { 2 - 4 } & $\begin{array}{c}\text { в цілому } \\
(\mathrm{n}=91)\end{array}$ & $\begin{array}{c}\text { порушення релаксації } \\
(\mathrm{n}=66)\end{array}$ & $\begin{array}{c}\text { псевдонормальний тип } \\
(\mathrm{n}=25)\end{array}$ \\
\hline E (см/с) & $58,8 \pm 2,8$ & $47,8 \pm 2,8 \cdot \bullet$ & $87,9 \pm 2,1$ \\
\hline A (см/с) & $71,4 \pm 2,4$ & $72,2 \pm 3,1$ & $68,6 \pm 2,4$ \\
\hline E/A (ум. од.) & $0,83 \pm 0,03$ & $0,66 \pm 0,01 \bullet \bullet$ & $1,28 \pm 0,01$ \\
\hline NT-рго ВNP (пг/мл) & $262,6 \pm 11,0$ & $231,9 \pm 10,2 \cdot \bullet$ & $378,7 \pm 18,4$ \\
\hline
\end{tabular}

Примітка. •- p<0,05; ••- p<0,001 з показниками ПН лШ групи зі збереженою ФВ.

Відомо, що в міру зростання віку знижується пікова швидкість раннього діастолічного потоку $\mathrm{E}$ та співвідношення Е/А, тоді як пікова швидкість пізнього потоку в систолу передсердь А зростає. E/A - найбільш досліджений показник діастолічної функції (ДФ). Згідно з Рекомендаціями робочої групи з функціональної діагностики Асоціації кардіологів України та Всеукраїнської асоціації фахівців з ехокардіографії, нормальні значення для досліджуваної вікової групи складають (M \pm SD) $(0,96 \pm 0,18)$ умовних одиниць. На основі аналізу показників трансмітрального кровотоку у хворих похилого віку з ІСАГ виділено такі типи порушень ДФ ЛШ: порушення релаксації (ПР) та псевдонормальний (ПН) тип.

У 66 (72,5 \%) хворих основної групи діагностовано трансмітральний кровотік за типом ПР ЛШ. При такому типі порушення ДФ ЛШ у пацієнтів основної групи швидкість наповнення ЛШ в фазу раннього діастолічного наповнення (Е) становила $(47,8 \pm 2,8)$ см/с і достовірно відрізнялась від даного показника при ПН типі ДД ( $<<0,001)$. Максимальна швидкість наповнення ЛШ під час систоли передсердя (А) мала значення $(72,2 \pm 3,1)$ см/с. 
Огляди літератури, оригінальні дослідження, погляд на проблему, випадок з практики, короткі повідомлення Відношення Е/А було достовірно нижчим, ніж такий показник у групі порівняння ( $<<0,001)$ і становило $(0,66 \pm 0,01)$, тобто було меншим, ніж 0,8. Отже, співвідношення $E / A$, яке нижче 1 ( $p<0,05)$, вірогідно вказує на перерозподіл кровотоку на користь систоли передсердя. У 48 (52,7 \%) пацієнтів діагностували концентричну глш. Ще в 18 (19,8 \%) хворих із порушенням релаксації ЛШ геометрична структура серця була представлена концентричним його ремоделюванням. Індекс ОЛПмакс. у всіх хворих з ДД за типом ПР лш перевищував 34 мл/м².

У 25 (27,5 \%) хворих з ІСАГ і ХСН зі збереженою ФВ ЛШ діагностували порушення діастолічного наповнення за типом ПН. В усіх випадках була діагностована концентрична ГЛШ. Показник Е та відношення Е/А достовірно відрізнялись від таких показників у хворих з ПР лш. Відношення Е/А перевищувало 0,8, але було меншим, ніж 2,0.

Пробу Вальсальви призначали для диференційної діагностики нормального і ПН типів трансмітрального кровотоку та для діагностики рестриктивного типу діастолічного наповнення лш. Пацієнти вдихали потік повітря в мундштук, прикріплений до звичайного сфігмоманометра, і витримували тиск 40 мм рт. ст. протягом 10 с. Позитивною пробу вважали при зміні висхідного співвідношення Е/А більше, ніж на 40 \%. На фоні зменшення венозного повернення ПН діастолічний потік переходить у спектр з ПР. Зменшення відношення Е/А трансмітрального потоку при пробі Вальсальви і з нітрогліцерином використовували як маркер підвищеного тиску наповнення ЛШ. Пацієнти з порушенням ДД за типом ПН мали концентричну ГЛШ та ІОЛПмакс. в них перевищував $34 \mathrm{Mл} / \mathrm{M}^{2}$.

Отже, у 66 (72,5 \%) хворих основної групи діагностували ДД за типом ПР. У 25 (27,5 \%) пацієнтів з ІСАГ зі збереженою ФВ реєстрували ПН тип наповнення ЛШ з позитивною пробою Вальсальви. Це вказує на субклінічне (приховане) підвищення тиску наповнення ЛШ. Отримані результати свідчать про гетерогенність порушень ДФ ЛШ при ХСН зі збереженою ФВ ЛШ у хворих похилого віку з ІСАГ.

У численних дослідженнях у первинній практиці встановлено, що сироваткові рівні мозкового натрійуретичного пропептиду (NT-ргоBNP) $<125$ пг/мл на 95-99 \% виключають наявність СН будь-якого типу. Дані щодо середнього рівня NTргоBNP у досліджуваній групі в залежності від типу ДД наведено в таблиці 2.

Аналіз NT-рго BNP довів, що в цілому по групі цей показник мав значення $(262,6 \pm 11,0)$ пг/мл. Але в залежності від типу ДД лШ рівень NT-рго BNP змінювався. Зареєстроване достовірне його

зростання у хворих із ПН типом ДД, порівняно з типом порушення релаксації $(p<0,001)$. Нами установлено, що зростання рівня NT-рго BNP понад 220 пг/мл є раннім критерієм порушення ДФ ЛШ.

Отже, аналіз порушень ДФ ЛШ і профілю його ремоделювання довів, що у хворих з ІСАГ діастолічна дисфункція Лш розвивається на тлі концентричного варіанта геометричної структури ЛШ, а саме, концентричної гіпертрофії та концентричного ремоделювання.

Європейське товариство кардіологів, окрім катетеризації серця, оцінку ДД Лш рекомендує проводити з використанням тканинної допплерографії. Найбільше поширення отримав показник Е/e' - співвідношення ранніх швидкостей трансмітрального потоку і кільця мітрального клапана. е' - рання діастолічна швидкість кільця мітрального клапана. За даними численних досліджень, саме показник E/е' корелює з інвазивним визначенням тиску заклинювання легеневих капілярів та/або кінцево-діастолічним тиском [5]. Серед параметрів оцінки діастолічної дисфункції, які наведені в поточних рекомендаціях ASE/EACVI [13], саме визначення E/e' має найбільшу доказовість щодо відображення тиску наповнення ЛШ. Відрізнити порушення ДД за типом ПН від нормального трансмітрального кровотоку допомагає виявлення зменшення швидкості E' руху мітрального кільця (при використанні тканинного доплера). Але існують деякі фактори, що обмежують його використання у людей похилого віку. Зокрема відомо, що з віком швидкість піку Е і е' зменшується. До того ж, в реальній практиці сімейного лікаря обстеження хворого із застосуванням тканинної допплерографії не можуть бути рутинними. Тому в повсякденній клінічній практиці двовимірна ехокардіографія з доплерографією є найкращим неінвазивним методом підтвердження діагнозу.

Розроблені нами критерії діагностики ХСН зі збереженою ФВ ЛШ у хворих похилого віку 3 ІСАГ: наявність клінічних симптомів ХСН при значеннях ФВ ЛШ > 50 \%, рівня Nt-рго BNP >125 пг/мл, концентричного варіанта ремоделювання ЛШ, переважно концентричної ГЛШ, ДФ ЛШ за типом ПР (E/A <0,8) або псевдонормалізації $(E / A>0,8<2,0)$ та індексу максимального об'єму ЛП >34 мл/м² $\epsilon$ доступними і доцільними в практиці сімейного лікаря.

Висновки. Провідним патогенетичним чинником виникнення ХСН із збереженою ФВ ЛШ $\epsilon$ діастолічна дисфункція ЛШ. Спектр порушень діастолічної функції лівого шлуночка залежить від профілю його ремоделювання.

У 66 (73\%) хворих з ІСАГ і ХСН зі збереженою ФВ лівого шлуночка діагностовано трансмітральний кровотік за типом порушення релаксації лШ. 
Огляди літератури, оригінальні дослідження, погляд на проблему, випадок з практики, короткі повідомлення

у 25 (27\%) хворих спостерігали порушення діастолічного наповнення за типом псевдонормалізації.

2. Визначення профілю порушень діастолічної функції лівого шлуночка у хворих з ІСАГ і ХСН зі збереженою ФВ лШ необхідне для подальшо- го проведення диференційної медикаментозної корекції його діастолічної дисфункції.

Перспективи подальших досліджень полягають в необхідності розробки диференційних підходів до лікування хворих похилого віку з ІСАГ та ХСН зі збереженою ФВ ЛШ.

\section{ЛІТЕРАТУРА}

1. Войцеховська К. В. Втрата маси тіла при хронічній серцевій недостатності: механізми та клінічне значення : автореф. дис. на здобуття наук. ступеня канд. мед. наук : 14.01.11 / Войцеховська Карина Віталіївна ; НАМН України, дУ "Нац. наук. центр Ін-т кардіології ім. акад. М.Д. Стражеска". - К., 2020. - 18 с.

2. Серцево-судинні захворювання. Класифікація, стандарти діагностики та лікування : монографія / за ред. В. Коваленко, М. Лутай, Ю. Сіренко [та ін.]. - 4-те вид. - К. : МOPIOH, 2020. - 240 с.

3. Voronkov L. G. Clinical and instrumental characteristics of patients with chronic heart failure and reduced left ventricular ejection fraction depending on weight loss within the previous 6 months / L. G. Voronkov, K. V. Voitsekhovska, L. P. Parascheniuk // Ukr. J. Cardiol. - 2019. Vol. 26 (2). - P. 48-56. DOI: https://doi.org/10.31928/1608$635 \mathrm{x}-2019.2 .4856$.

4. The interrelationship of bone and cardiovascular remodeling biomarkers and clinical peculiarities of coronary artery disease in postmenopausal women / N. S. Mykhailovska, I. O. Stetsiuk, T. O. Kulynych [et al.] // Reumatologia. - 2020. - Vol. 58 (3). - P. 142-149.

5. Василенко О. В. Фенотипи хронічної серцевої недостатності зі збереженою фракцією викиду лівого шлуночка. Клінічне та діагностичне значення : автореф. дис. на здобуття наук. ступеня канд. мед. наук / Василенко Ольга Володимирівна ; НАМН України, дУ "Нац. наук. центр Ін-т кардіології ім. акад. М. Д. Стражеска". - К., 2019. - 19 с.

6. Рекомендації Асоціації кардіологів України 3 діагностики та лікування хронічної серцевої недостатності / Л. Г. Воронков, К. М. Амосова, А. Е. Багрій [та iн.]. - К. : УАФСН, 2017. -68 с.

7. Кадирова Ф. С. Клінічний перебіг хронічної серцевої недостатності із збереженою та проміжною фракцією викиду лівого шлуночка / Ф. С. Кадирова, М. Є. Рахі- мова // Здобутки клініч. і експерим. медицини. - 2019. № 4. - C. 78-81. DOI: https://doi.org/10.11603/1811-2471. 2019.v.i4.10797.

8. Skybchyk V. A. Chronic heart failure: new approaches to diagnosis and treatment / V. A. Skybchyk // Medicine of Ukraine. - 2016. - № 10 (206). - P. 34-41. DOI: https://doi.org/10.37987/1997-9894.2016.10(206). 207666.

9. 36 months survivability and its predictors in patients with chronic heart failure and decreased fraction of left ventricular ejection depending on sex / L. Voronkov, E. Filatova, A. Lyashenko [et al.] // EUREKA: Health Sciences. - 2017. - Vol. 5. - P. 44-49. DOI: 10.21303/ 2504-5679.2017.00408.

10. Шейко С. О. Особливості структурно-функціонального стану серця в гірників з артеріальною гіпертензією / С. О. Шейко, А. М. Василенко, Н. О. Колб // Медичні перспективи. - 2018. - Т. XXIII, № 3 (Ч. 1). - С. 258259. - Режим доступу: http://nbuv.gov.ua/UJRN/Mp_ 2018_23_3(1)_54.

11. Curfman G. Treatment and Control of Hypertension in 2020 / G. Curfman, H. Bauchner, P. Greenland // JAMA. - 2020. - Vol. 324 (12). - P. 1166. DOI: https:// doi.org/10.1001/jama.2020.13322.

12. 2016 ESC Guidelines for the diagnosis and treatment of acute and chronic heart failure / P. Ponikowski, A. A. Voors, S. D. Anker [et al.] // Kardiologia Polska. 2016. - Vol. 74, № 10. - P. 1037-1147. - URL: https:// doi.org/10.5603/kp.2016.0141.

13. Recommendations on the use of echocardiography in adult hypertension: a report from the European Association of Cardiovascular Imaging (EACVI) and the American Society of Echocardiography (ASE) / T. H. Marwick, T. C. Gillebert, G. Aurigemma [et al.] // J. Am. Soc. Echocardiogr. 2015. - Vol. 28 (7). - P. 727-754. DOI: 10.1016/j.echo. 2015.05.002.

\section{REFERENCES}

1. Voitsekhovska, K.V. (2020). Vtrata masy tila pry khronichnii sertsevii nedostatnosti: mekhanizmy ta klinichne znachennia [Weight loss in chronic heart failure: mechanisms and clinical significance]. Extended abstract of candidate's thesis. Kyiv: NAMN Ukrainy, In-t kardiolohii im. akad. M.D. Strazheska [in Ukrainian].

2. Kovalenko, V., Lutay, M., Sirenko, Yu., \& Sychov, O. (2020). Sertsevo-sudynni zakhvoriuvannia. Klasyfikatsiia, standarty diahnostyky ta likuvannia: monohrafiia [Cardio- vascular diseases. Classification, standards of diagnosis and treatment: monograph]. 4st edn. Kyiv: MORION [in Ukrainian].

3. Voronkov, L.G., Voitsekhovska, K.V., \& Parascheniuk, L.P. (2019). Clinical and instrumental characteristics of patients with chronic heart failure and reduced left ventricular ejection fraction depending on weight loss within the previous 6 months. Ukr. J. Cardiol., 26 (2), 48-56. DOI: https://doi.org/10.31928/1608-635x-2019.2.4856 
Огляди літератури, оригінальні дослідження, погляд на проблему, випадок з практики, короткі повідомлення

4. Mykhailovska, N.S., Stetsiuk, I.O., Kulynych, T.O. Gorbachova, S.V., \& Zhulkevych, I.V. (2020). The interrelationship of bone and cardiovascular remodeling biomarkers and clinical peculiarities of coronary artery disease in postmenopausal women. Reumatologia, 58 (3), 142-149. DOI: $10.5114 /$ reum.2020.96687.

5. Vasylenko, O.V. (2019). Fenotypy khronichnoi sertsevoi nedostatnosti zi zberezhenoiu fraktsiieiu vykydu livoho shlunochka. Klinichne ta diahnostychne znachennia [Fenotypy khronichnoi sertsevoi nedostatnosti zi zberehenoiu fraktsiieiu vykydu livoho shlunochka. Klinichne ta diahnostychne znachennia]. Extended abstract of candidate's thesis. NAMN Ukrainy, In-t kardiolohii im. akad. M. D. Strazheska [in Ukrainian].

6. Voronkov, L., Amosova, K., Zharinov, O., Kovalenko, V., Korkushko, O., Nesukai, O., \& Sychov, O. (2017). Rekomendatsii Asotsiatsii kardiolohiv Ukrainy z diahnostyky ta likuvannia khronichnoi sertsevoi nedostatnosti [Recommendations of the Association of Cardiologists of Ukraine for the diagnosis and treatment of chronic heart failure]. Kyiv: UAFSN [in Ukrainian].

7. Kadyrova, F.S., \& Rakhimova, M.E. (2019). Klinicheskoye techeniye khronicheskoy serdechnoy nedostatochnosti s sokhranennoy i promezhutochnoy fraktsiyey vybrosa levogo zheludochka [The clinical course of chronic heart failure with preserved and intermediate left ventricular ejection fraction]. Zdobutky klinichnoi i eksperymentalnoi medytsyny - Achievements of Clinical and Experimental Medicine, 4, 78-81. DOI: https://doi.org/10.11603/18112471.2019.v.i4.10797 [in Russian].
8. Skybchyk, V.A. (2016). Chronic heart failure: new approaches to diagnosis and treatment. Medicine of Ukraine, 10 (206), 34-41. DOI: https://doi.org/10.37987/19979894.2016.10(206).207666

9. Voronkov, L., Filatova, E., Lyashenko, A., Tkach, N., \& Babych, P. (2017). 36 months survivability and its predictors in patients with chronic heart failure and decreased fraction of left ventricular ejection depending on sex. EUREKA: Health Sciences, 5, 44-49. DOI: https://doi. org/10.21303/2504-5679.2017.00408

10. Sheiko, S., Vasylenko, A., \& Kolb, N. (2018). Osoblyvosti strukturno-funktsionalnoho stanu sertsia v hirnykiv z arterialnoiu hipertenziieiu [Peculiarity of the structural and functional state of the heart in miners with hypertension]. Medychni perspektyvy-Medical Prospects, XXIII, 3 (1), 258-259. Retrieved from: http://nbuv.gov.ua/UJRN/ Mp_2018_23_3(1)_54 [in Ukrainian].

11. Curfman, G., Bauchner, H., \& Greenland, P. (2020). Treatment and Control of Hypertension in 2020. JAMA, 324 (12), 1166. DOI: https://doi.org/10.1001/jama.2020.13322

12. Ponikowski, P., Voors, A., \& Anker, S. (2016). 2016 ESC Guidelines for the diagnosis and treatment of acute and chronic heart failure. Kardiologia Polska, 74 (10), 1037 1147. DOI: 10.5603/KP.2016.0141

13. Marwick, T.H., Gillebert, T.C., Aurigemma, G., Chirinos, J., Derumeaux, G., Galderisi, M., \& Zamorano, J.L. (2015). Recommendations on the use of echocardiography in adult hypertension: a report from the European Association of Cardiovascular Imaging (EACVI) and the American Society of Echocardiography (ASE). J. Am. Soc. Echocardiogr., 28 (7), 727-754. DOI: 10.1016/j.echo.2015.05.002

\title{
ХРОНИЧЕСКАЯ СЕРДЕЧНАЯ НЕДОСТАТОЧНОСТЬ У БОЛЬНЫХ ПОЖИЛОГО ВОЗРАСТА С ИЗОЛИРОВАНОЙ СИСТОЛИЧЕСКОЙ АРТЕРИАЛЬНОЙ ГИПЕРТЕНЗИЕЙ
}

\section{๑С. А. Шейко, Н. А. Колб}

\author{
ГУ «Днепропетровская медицинская академия МОЗ Украины»
}

РЕЗЮМЕ. У пациентов с изолированной систолической артериальной гипертензией (ИСАГ) к развитию хронической сердечной недостаточности (ХCH) приводят длительное течение болезни, структурно-функциональная перестройка и нарушение геометрической модели сердца. Определенный вклад в формирование XСH с сохраненной фракцией выброса (ХСНсохрФВ) левого желудочка (ЛЖ) у больных пожилого возраста имеют возрастные изменения сердца. Несмотря на значительные успехи в диагностике и лечении больных пожилого возраста с ИСАГ, особенности развития и критерии диагностики ХСН у данной категории пациентов в настоящее время остаются недостаточно изученными.

Цель - изучить особенности развития и разработать критерии диагностики ХСН у больных пожилого возраста с ИСАГ.

Материал и методы. Обследовали 134 больных пожилого возраста с ИСАГ. В основную группу включили 91 пациента в возрасте $(71,1 \pm 3,5)$ лет с ИСАГ, с ФВ ЛЖ >50 \% и уровнем NT-рго BNP >125 пг/мл. Среди них 61 женщина (67 \%) и 30 (33\%) мужчин. Группу сравнения составили 43 пациента (27 женщин и 16 мужчин в возрасте $(70,4 \pm 3,7)$ года) с ИСАГ, ФВ ЛЖ >50 \% и NT-рго ВNP <125 пг/мл. Структурно-функциональное состояние сердца изучали с помощью одно- и двухмерной эхокардиографии. Объемные показатели лЖ и левого предсердия (ЛП) рассчитывали по методу Simpson. Трансмитральный кровоток оценивали по рекомендациям Европейской ассоциации кардиоваскулярной визуализации и Американской ассоциации эхокардиографии. NT-рго BNP в плазме крови определяли с помощью хемилюминесцентного иммуноферментного анализа.

Результаты. У 66 (72,5 \%) больных основной группы диагностирована диастолическая дисфункция (ДД) по типу нарушения релаксации (НР) ЛЖ. У 25 (27,5 \%) пациентов с ИСАГ и ХСНсохрФВ диагностировали нарушение диастолической функции (ДФ) по типу псевдонормализации (ПН). Во всех случаях имела место концентрическая ГЛЖ. Независимо от пола уровень индекса максимального объема ЛП (ИОЛПмакс.) превышал 34 мл/м². Разработаны критерии диагностики ХСНсохрФВ ЛЖ у больных с ИСАГ: наличие клинических симптомов СН при значе- 
Огляди літератури, оригінальні дослідження, погляд на проблему, випадок з практики, короткі повідомлення ниях ФВ ЛЖ >50 \%, уровня Nt-рго BNP >125 пг/мл, концентрического варианта ремоделирования лЖ, преимущественно концентрической ГЛЖ, ДД ЛЖ по типу НР (E/A<0,8) или ПН $(E / A>0,8<2,0)$ и ИОЛПмакс. >34 мл/м².

Выводы. Ведущим патогенетическим фактором возникновения ХСНсохрФВ является ДД ЛЖ. Спектр нарушений ДФ ЛЖ зависит от профиля его ремоделирования. У 66 (73 \%) больных с ИСАГ и ХСНсохрФВ диагностирована ДД по типу НР ЛЖ. У 25 (27 \%) больных наблюдали нарушения диастолического наполнения по типу ПН. Определение профиля нарушений ДФ ЛЖ у больных с ИСАГ и ХСНсохрФВ необходимо для дальнейшего проведения дифференцированной медикаментозной коррекции его ДД.

КЛЮЧЕВЫЕ СЛОВА: изолированная систолическая артериальная гипертензия; хроническая сердечная недостаточность; сохраненная фракция выброса; диастолическая дисфункция; пожилой возраст.

\section{CHRONIC HEART FAILURE IN ELDERLY PATIENTS WITH ISOLATED SYSTOLIC ARTERIAL HYPERTENSION}

\section{Dnipropetrovsk Medical Academy}

@S. O. Sheiko, N. O. Kolb

SUMMARY. In patients with isolated systolic arterial hypertension (ISAH), the development of chronic heart failure (CHF) leads to a long course of the disease, structural and functional adjustment and impairment of the geometric model of the heart. Age-related changes in the heart of the left ventricle (LV) in elderly patients have a certain contribution to the formation of CHF with preserved ejection fraction (EF). Despite significant advances in the diagnosis and treatment of elderly patients with ISAH, the features of development and criteria for the diagnosis of CHF in this category of patients are currently insufficiently studied.

The aim - to study the features of development and work out criteria for the diagnosis of CHF in elderly patients with ISAH.

Material and Methods. There were examined 134 elderly patients with ISAH. The main group included 91 patients aged $71.1 \pm 3.5$ years with ISAH, LV EF>50 \% and NT-pro BNP level>125 pg / ml. Of them there were 61 women (67 \%) and 30 (33\%) men. The comparison group consisted of 43 patients (27 women and 16 men aged $70.4 \pm 3.7$ years) with ISAH, LV EF $>50 \%$ and NT-pro BNP $<125$ pg/ml. The structural and functional state of the heart was studied using one- and twodimensional echocardiography. LV and left atrial volume (LV) were calculated by the Simpson method. Transmitter blood flow was assessed according to the recommendations of the European Association of Cardiovascular Imaging and the American Association of Echocardiography. NT-pro BNP in blood plasma was determined by chemiluminescent enzymelinked immunosorbent assay.

Results. Diastolic dysfunction (DD) was diagnosed in 66 (72.5\%) patients of the main group according to the type of LV relaxation disorder (RD). In 25 (27.5\%) patients with ISAH and CHFpEF diastolic dysfunction (DD) by the type of pseudonormalization (PN) was diagnosed. In all cases, there was a concentric LVH. Regardless of gender, the level of the index of maximum volume of LA (IVLAmax.) exceeded $34 \mathrm{ml} / \mathrm{m}^{2}$. Criteria for the diagnosis of LV CHF in patients with ISAH have been developed: the presence of clinical symptoms of HF at LV EF values $>50 \%$, Nt-pro BNP level $>125 \mathrm{pg} / \mathrm{ml}$, concentric LV remodeling variant, mainly concentric LV, LV DD by type RD $(E / A<0.8)$ or $P N(E / A>0.8<2.0)$ and ILAPmax.>34 ml/m².

Conclusions. The leading pathogenetic factor of heart failure is LV DD.

The range of LV DF disorders depends on the profile of its remodeling. In 66 (73\%) patients with ISAH and CHFpEF, DD was diagnosed by the type of LV RD. In 25 (27\%) patients there were impairments of diastolic filling by PN type. Determining the profile of LV DF disorders in patients with ISAH and CHFpEF is necessary for further differentiated drug correction of DD.

KEY WORDS: isolated systolic arterial hypertension; chronic heart failure; preserved ejection fraction; diastolic dysfunction; old age. 